\title{
The Effect of Co-Administration of Telang Leaves Ethanolic Extract Towards Fluoxetin's Sedative Effect on Male Balb/C Mice Based on Sleeping Duration Parameter
}

\author{
Anif Nur Artanti*, Maria Ulfah \\ Department of Pharmacy, Faculty of Mathematics and Sciences, Universitas Sebelas Maret Surakarta, \\ Indonesia
}

\begin{abstract}
One of Telang plant's advantages is its activity as sedative agent. Previous studies indicate that Telang plant has anticonvulsant activity on mice at certain dose. This study was conducted to find out the sedative effect of Telang plant, particularly its leaf, when being coadministered with fluoxetin. Phytochemical analysis was carried out qualitatively on Telang ethanolic extract leaves (TEE) to find out the content of chemical compound first. This study was an experimental research with post-test only control group design, employing male balb/c mice. The effect of Telang ethanolic extract co-administration with fluoxetin was observed. The parameter being used in the study was the duration of sleep. Analysis was done by comparing mice sleeping duration prior to administration of fluoxetin alone and in combination with Telang ethanolic extract. The data was then analyzed using SPSS 17.0 for Windows. The results showed that TEE contained tannin, saponin, and flavonoid compounds, and co-administration of TEE and fluoxetin at various doses could provide sedative effect on mice. The co-administration of $400 \mathrm{mg} / \mathrm{kgBW}$ extract and $15 \mathrm{mg} / \mathrm{kgBW}$ fluoxetin could provide the mean sleeping duration 43 minutes longer than positive control.
\end{abstract}

Keywords: telang leaves ethanol extract, fluoxetin, sleeping duration.

\section{INTRODUCTION}

One of the application of herbal medicine is to treat sleeping disorder. It was estimated that in every year, there were as many as $20-40 \%$ adults having chronic sleep and wakefulness sleeping disorders (National Sleep Foundation, 2011). The prevalence of sleeping disorder every year has been increasing, caused by aging and other causes. Based on Indonesian Department of Health, the number of older society having sleeping disorder each year reaches 750 people. Insomnia is the most prevalent sleep disorder among adults. The estimated prevalence of difficulty in initiating and maintaining sleep is about $30 \%$ (LeBlanc, et al, 2007). Regarding to those problems, Telang plants (Clitoria ternatea L.) is known to have some benefits.

In several regions in Indonesia, this plant is traditionally used as laxative, diuretic, anthelmintic, intelligence-promoting, and anti- inflammatory properties and they are useful in severe bronchitis, asthma and dementia, hemicrania, burning sensation, leprosy, inflammation, leucoderma, pulmonary tuberculosis, ascites, and hectic fever (Mukherjee, et al., 2008). The leaves and roots of Telang plants are used as the medicine for several diseases, such as peripheral pain, infection, and urogenital disturbance (Patil and Patil, 2011). Telang's roots extract is used in the medication of amnesia (Ravishankar and Parvathi, 2012). Telang plant is reported to possess some pharmacological activities, such as antimicrobial, antipiretic, antiinflammation, analgesic, antidiabetic, insecticide, and relaxant (Mukherjee, et al., 2008).

\footnotetext{
*Corresponding author e-mail: aniph_q@yahoo.com
} 
Several previous studies reported that TEE showed the modulation of obsessivecompulsive behaviour in mice which have the comparable effect to fluoxetine in the dose range of 5,10 , and $15 \mathrm{mg} / \mathrm{kgBW}$ (Shende, et al., 2012).

Ethanolic extract of Telang in the dose of 100,200 , and $499 \mathrm{mg} / \mathrm{kgBW}$ did not induce sedative activity, but higher dose showed the potential of sedative activity (Kulkarni, 1998). Therefore, in this paper, we studied the sedative effect of TEE if it is co-administrated with fluoxetine in order to reduce the therapeutic dose of fluoxetine. Besides, the initial qualitative study of the compounds contained in this extract was also conducted.

\section{MATERIALS AND METHODS}

\section{Ethanolic extract of Telang Leaves (TEE)}

As many as one kilogram of Clitoria ternatea leaves is obtained from Rejosari village, Madiun, Jawa Timur, Indonesia. The leaves were cleaned, then dried by using oven in the temperature of $50^{\circ} \mathrm{C}$ and powdered. The extraction of powder was done by ethanol $70 \%$, and evaporated by rotary evaporator.

\section{Qualitative Phytochemistry Assay for Alkaloid Content}

As many as $2 \mathrm{~mL}$ of TEE was added by 1 $\mathrm{mL}$ of HCL $2 \mathrm{~N}$ and $9 \mathrm{~mL}$ of hot water, and heated in the temperature of $100^{\circ} \mathrm{C}$ for 2 minutes. Then the mixture was cooled down and filtrated. Approximately 3 drops of filtrate were added by Wragener reagent on the glass and the formation of brown sediment as a sign of the existence of alkaloid was observed.

\section{Qualitative Assay for Tannin Content}

Approximately $2 \mathrm{~mL}$ of TEE was added by $10 \mathrm{~mL}$ of hot water, heated in the water incubator in the themperature of $100^{\circ} \mathrm{C}$ for an hour, and filtrated as it is cooled down. Filtrate was dropped by $1 \%$ Iron (III) chloride. The blue-green or black colour showed the existence of tannin.

\section{Qualitative Assay for Saponin Content}

As many as $2 \mathrm{~mL}$ of TEE were added by $10 \mathrm{~mL}$ hot water, then it was cooled and shaked for
10 minutes or until stable foam was formed as high as $1-10 \mathrm{~cm}$. Saponin content is shown by the existence of the foam after the addition of $2 \mathrm{~N}$ $\mathrm{HCl}$.

\section{Qualitative Assay for Flavonoid Content}

As many as $2 \mathrm{~mL}$ of TEE were added by the powder of $\mathrm{Mg}, 1 \mathrm{~mL} \mathrm{HCl}$ :ethanol 70\% (10:10), and some amyl-ethanol until two layers were formed. Positive result is showed by the color of layer become yellow, bright red, or red.

\section{Qualitative Assay for Triterpenoid Content}

As many as $2 \mathrm{~mL}$ of TEE were added by ethanol $70 \%$ and heated, and filtered. Filtrate then was evaporated and added by ether. The ether layer was taken and dropped by LiebermannBurchard reagent (3 drops of Acetic acid anhydrate +1 drop of $\mathrm{H}_{2} \mathrm{SO}_{4}$ ). Positive result is shown by the formation of green to blue color.

\section{In Vivo Assay for Sedative Effect of TEE}

As many as $18 \mathrm{balb} / \mathrm{c}$ male mice were used in the treatment. The tested animals were divided into 6 groups, each of which consisted of 3 mice. Group I was negative control given CMC p.o., group II was positive control given 20 $\mathrm{mg} / \mathrm{kgBW}$ fluoxetin i.p., group II was given 100 $\mathrm{mg} / \mathrm{kgBW}$ TEE p.o. and $5 \mathrm{mg} / \mathrm{kgBW}$ fluoxetin i.p., group IV was given $200 \mathrm{mg} / \mathrm{kgBW}$ TEE p.o. and $10 \mathrm{mg} / \mathrm{kgBW}$ fluoxetin i.p., group $\mathrm{V}$ was given $500 \mathrm{mg} / \mathrm{kgBW}$ TEE p.o. and $15 \mathrm{mg} / \mathrm{kgBW}$ fluoxetin i.p., and group VI was given 400 $\mathrm{mg} / \mathrm{kgBW}$ TEE p.o. The sedative effect were analyzed by the observation of the sleeping duration of the mice.

\section{Data Analysis}

Data were analyzed by SPSS 17.0 for windows one Way ANOVA (Analysis of Variance) continued by Post Hoc Test $(p<0.05)$ to define the significance of differences between groups.

\section{RESULTS}

The results of this study are shown below (Fig. 1, Fig. 2, and Table 1). 


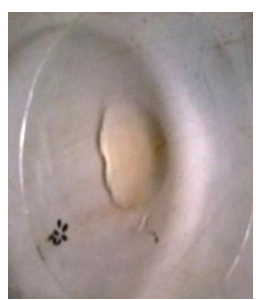

(A)

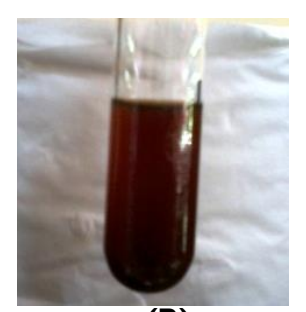

(B)

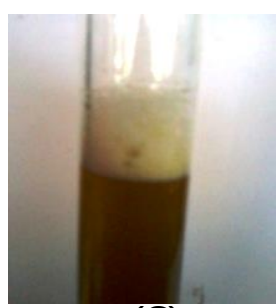

(C)

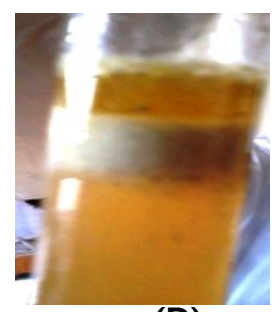

(D)

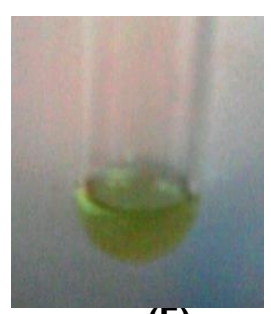

(E)

Figure I. The result of Qualitative Phytochemistry Assay. It showed that the TEE contain no alkaloid by showing no brown precipitate $(A)$, meanwhile the Tannin assay showed positive result by forming black color solution (B), stable foam until \pm 10 minutes $(1.5 \mathrm{~cm})$ showed the existence of Saponin (C), Flavonoid content showed by two layers having the color yellow to reddish yellow (D), and green color showed the positive result for Triterpenoid content (E).

Table I. The effects of TEE on sleeping duration of mice

\begin{tabular}{|c|c|c|c|c|c|c|}
\hline \multirow[b]{2}{*}{ Replication } & \multicolumn{6}{|c|}{ Sleeping duration of each groups (minutes) } \\
\hline & $\begin{array}{c}\text { Negative } \\
\text { control }\end{array}$ & $\begin{array}{l}\text { Positive } \\
\text { control }\end{array}$ & $\begin{array}{c}\text { Fluoxetin } 5 \\
\mathrm{mg} / \mathrm{kgBW} \\
+\mathrm{TEE} \\
100 \mathrm{mg} / \mathrm{kgBW}\end{array}$ & $\begin{array}{c}\text { Fluoxetin } 10 \\
\mathrm{mg} / \mathrm{kgBW} \\
+\mathrm{TEE} \\
200 \mathrm{mg} / \mathrm{kgBW}\end{array}$ & $\begin{array}{c}\text { Fluoxetin } \\
\text { I } 5 \mathrm{mg} / \mathrm{kgBW} \\
+\mathrm{TEE} \\
400 \mathrm{mg} / \mathrm{kgBW}\end{array}$ & $\begin{array}{c}\text { TEE } 400 \\
\mathrm{mg} / \mathrm{kgBW}\end{array}$ \\
\hline I & 0 & 162 & 120 & 160 & 200 & 90 \\
\hline 2 & 0 & 167 & 122 & 163 & 215 & 100 \\
\hline 3 & 0 & 180 & 128 & 164 & 224 & 105 \\
\hline Mean \pm SD & 0 & $\begin{array}{r}169.67 \\
\pm 9.292\end{array}$ & $\begin{array}{c}123.33 \pm \\
4.163\end{array}$ & $\begin{array}{c}162.33 \pm \\
2.082\end{array}$ & $\begin{array}{c}213.00 \pm \\
0.02\end{array}$ & $\begin{array}{c}98.33 \pm \\
7.638\end{array}$ \\
\hline
\end{tabular}

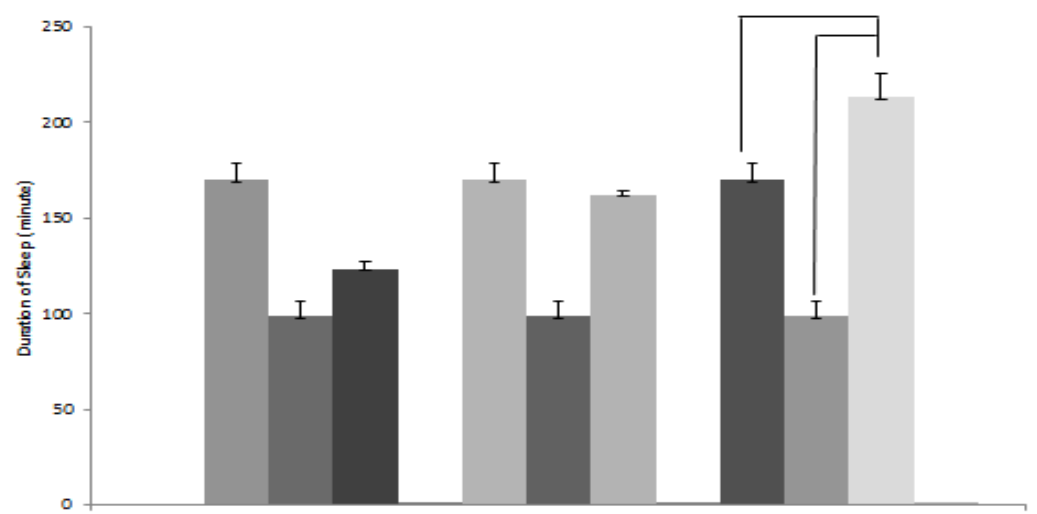

\begin{tabular}{|c|c|c|c|c|c|c|c|c|c|}
\hline Fluoxetin $20 \mathrm{mg} / \mathrm{kg} \mathrm{BW}$ & + & - & - & + & - & - & + & - & - \\
\hline TEE $400 \mathrm{mg} / \mathrm{kg} \mathrm{BW}$ & - & + & - & - & + & - & - & + & - \\
\hline Fluoxetin $5 \mathrm{mg} / \mathrm{kg} \mathrm{BW}$ & - & - & + & - & - & - & - & - & - \\
\hline TEE $100 \mathrm{mg} / \mathrm{kg}$ BW & - & - & + & - & - & - & - & - & - \\
\hline Fluoxetin $10 \mathrm{mg} / \mathrm{kg} \mathrm{BW}$ & - & - & - & - & - & + & - & - & - \\
\hline TEE 200 mg/kg BW & - & - & - & - & - & + & - & - & - \\
\hline Fluoxetin $15 \mathrm{mg} / \mathrm{kg} \mathrm{BW}$ & - & - & - & - & - & - & - & - & + \\
\hline TEE $400 \mathrm{mg} / \mathrm{kg}$ BW & - & - & - & - & - & - & - & - & + \\
\hline
\end{tabular}

Figure 2. Result of sedative effect observation by using sleep duration as the parameter. The Table showed a significant difference between positive control and co-administration of Fluoxetin and TEE. 


\section{DISCUSSION}

Phytochemical screening is a qualitative method used to determine the secondary metabolites of crude extract. This study showed that Telang leaves contains tannin, saponin, flavonoid, and triterpenoid.

Sedative effect was reviewed from mice's sleeping time duration after received treatment. The duration was started once sedative effect was shown and finished when the mice woke up and could do some activities as before-treatment phase. This study showed that higher co-administration fluoxetin and TEE dose increased sleeping time of mice.

For each treatment and test, separate groups of mice were used. Mice were injected with saline $(10 \mathrm{~mL} / \mathrm{kgBW}$, p.o.), fluoxetin, and/or TEE as describe above and individual mouse was observed for sleeping time duration from locomotor activity. One-way ANOVA indicated the significant influence of TEE (100, 200 , and $400 \mathrm{mg} / \mathrm{kgBW}$, p.o.) dose-dependently on sleeping time duration compared to control. Newman-keuls test indicated that TEE (100, 200 , and $400 \mathrm{mg} / \mathrm{kgBW}$, p.o.) decreased marble-burying behavior in mice in a dosedependent manner. Figure 1 and figure 2 showed that TEE did not affect motor activity compared to the saline treated group ( $p>0.05$ ).

Post Hoc Test showed no significant difference between positive control and coadministration of fluoxetin $5 \mathrm{mg} / \mathrm{kgBW}$ and also TEE $100 \mathrm{mg} / \mathrm{kgBW}$ (group I) $(p>0.05)$. Co-administration of $10 \mathrm{mg} / \mathrm{kgBW}$ fluoxetin and $200 \mathrm{mg} / \mathrm{kgBW}$ TEE (group II) also showed no significant differences $(p>0.05)$. Coadministration of $15 \mathrm{mg} / \mathrm{kgBW}$ fluoxetin and $400 \mathrm{mg} / \mathrm{kgBW}$ TEE (group III) and 400 $\mathrm{mg} / \mathrm{kgBW}$ TEE (group IV) showed significant differences $(p<0.05)$ compared to positive control which means group IV gave different sedative effect to positive control. The combination of TEE $400 \mathrm{mg} / \mathrm{kgBW}$ and fluoxetin $15 \mathrm{mg} / \mathrm{kgBW}$ gave sedative effect more than positive control.

\section{CONCLUSION}

Qualitative phytochemical screening showed that TEE contains tannin, saponin, and flavonoid. TEE administrated with the dose of $400 \mathrm{mg} / \mathrm{kgBW}$ followed by $15 \mathrm{mg} / \mathrm{kgBW}$ fluoxetin performed sedative effect with average of sleeping time duration was 43 minutes longer than single administration of $400 \mathrm{mg} / \mathrm{kgBW}$ fluoxetin.

\section{REFERENCES}

Guillaume, J., Kaushik, S., Bergot, P. and Metailler, R., 200I, Nutrition and Feeding of Fish and Crustaceans, Chichester: Praxis Publishing.

Harborne, J.B., 1987, Metode Fitokimia: Penuntun Cara Modern Menganalisis Tumbuhan, First Edition, Bandung: ITB Press.

Harborne, J.B., 1996, Metode Fitokimia: Penuntun Cara Modern Menganalisis Tumbuhan, Second Edition, Bandung: ITB Press.

Japardi, I., 2002, Gangguan Tidur, Medan: Faculty of Medicine Universitas Sumatera Utara.

Ravishankar, K. and Parvathi M., 2012, Study of Protective Effect of Ethanolic Root Extract of Clitoria Ternatea Against Stress Induced Amnesia, J. Pharm. Res., 5(5), 2763-2766.

Kartikar, K.R. and Basu B.D, 1935, Indian Medicinal Plants, Allahabad: Lalit Mohan Basu Publications.

Kulkarni, C., Pattanshetty, J.R. and Amruthraj G., 1988, Effect of Alcoholic Extract of Clitoria ternatea Linn. on Central Nervous System in Rodents, Indian J. Exp Biology, 26(I2), 957-960.

LeBlanc, M., Beaulieu-Bonneau, S., Merette, C., Savard J., Ivers H. and Morin, C.M., 2007, Psychological and Health-Related Quality of Life Factors Associated with Insomnia in A Populationbased Sample, J Psychosom Res., 63(2), I57-I66.

Mukherjee, P.K., Kumar, V., Kumar, N.S. and Heinrich, M., 2008, The Ayurvedic Medicine Clitoria ternatea from Traditional Use to Scientific Assessment, J. Ethnopharmacol, I 20(3), 29I-30I.

Nakagawa, H., Sato M. and Gatlin III, D.M., 2007, Dietary supplement for the health and quality of cultured fish, Trowbridge: Cromwell Press. 
National Sleep Foundation, 2010, How much sleep do we really need? Washington, DC: National Sleep Foundation, http://www.sleepfoundation.org/article/ho w-sleep-works/how-much-sleep-dowereally-need, accessed February 22, $20 \mathrm{II}$.

Patil, A.P. and Patil, V.R., 20II, Clitoria ternatea Linn.: An overview. Int. J. Pharm, Res., 3(I), 20-23.

Mukherjee, P.K., Kumar, V., Kumar, N.S. and Heinrich, M, 2008, The Ayurvedic Medicine Clitoria ternatea From Traditional Use to Scientific Assessment. J. Etnopharmacol., I 20(2008), 29I-30 I.

Sanjayasari, Dyahruri and Pililiang, W.G., 20II, Skrining Fitokimia dan Uji Toksisitas Ekstrak Daun Katuk (Saoropus androgenus
L. Merr) terhadap Larva Udang Artemia Salina: Potensi Fitofarmaka pada Ikan, Berkala Pertanian Terubuk, 39(I), 9I-I00.

Sediarso and Rusdi, N.K., 2010, Pengaruh Ekstrak Akar Cabe Jawa (Piper retrovractum Vahl) terhadap Fertilitas Mencit Jantan Berdasarkan Peningkatan Jumlah Sperma, Usulan Hibah Kompetitif Penelitian Strategis Nasional, Jakarta: Universitas Muhammadiyah H Prof. DR. Hamka.

Setiawan, A., 2007, Mengenal Jenis Anti Nutrisi pada Bahan Pakan, Buletin CP, 96(8), n.p.

Shende, V., Rajkumari S., Mayuri L., Naeem H. and Harshada L., 20I2, Evaluation of Anti-complisuve Effect of ethanolic Extract of Clitoria ternatea in Mice, Asian J. Pharm. Clin. Res., 5(3), I20-I 23. 